\title{
Migration with pension reform expectations
}

\author{
MAREK GÓRA, Professor* \\ ANNA RUZIK-SIERDZIŃSKA, Ph.D.*
}

Article**

JEL: F22, J24, J26, J61

https://doi.org/10.3326/pse.44.2.3

\footnotetext{
* The authors would like to thank the two anonymous referees for helpful comments on the paper which was prepared as part of research activities at the Warsaw School of Economics. No other financial support has been used. An earlier version has been published as IZA Discussion Paper No 11960.

${ }^{* *}$ Received: July 31, 2019

Accepted: October 19, 2019
}

\section{Marek GÓRA}

Warsaw School of Economics, al. Niepodległości 162, 02-554 Warsaw, Poland and Institute of Labor Economics (IZA), Bonn, Germany

e-mail: marek.gora@sgh.waw.pl

ORCiD: 0000-0001-9117-1603

Anna RUZIK-SIERDZIŃSKA

Warsaw School of Economics, al. Niepodległości 162, 02-554 Warsaw, Poland

e-mail: anna.ruzik@sgh.waw.pl

ORCiD: 0000-0003-3919-0289 


\section{Abstract}

Pension reforms, which imply a reduction in the generosity of pension benefits, are becoming widespread in response to the demographic transition. The scale, the timing, and the pace of these reforms vary across countries. In this theoretical article, the authors analyse individual migration decisions, by adding a component linked to the expected old-age pension benefits in sending and receiving countries in two cases: when the pension system rules are known, and when there is a risk of pension systems reforms. The results indicate that when individuals fail to take future pension wealth into account, they can make sub-optimal migration decisions.

Keywords: migration decisions, pension benefits, pension reforms, institutional uncertainty

\section{INTRODUCTION}

Public pension systems and public finance in general have been suffering from the consequences of the demographic transition; namely, from the disappearance of the demographic dividend, whereby the presence of a large younger generation in the labour market enabled countries to provide relatively generous pensions to older generations. The easily available and cheap method of rolling public debt is no longer effective. ${ }^{1}$ In response to this shift, countries are looking for ways to reduce public expenditures, which generally include reforming the pension system, either currently or in the future. In the latter type of pension reform, the generosity of future pension benefits is reduced, and/or it is made more difficult for future retirees to claim benefits or other publicly financed transfers. Can we predict in which countries such reforms will be more extreme or will be implemented more quickly, and in which countries these changes will be introduced more gradually? If it is difficult for experts to make such predictions, it is hardly possible for ordinary people to do so. The only certainty is that pension systems will become less generous. However, the pace at which the pension reform process occurs is likely to vary greatly across countries.

Some individuals migrate internationally. According to the literature, the decision about whether and where to migrate depends on a number of factors. Among the most important factors are differences in the standard of living between countries. For economic migrants, these differences can be measured by the gap between the available wage at home and abroad. Migrants are usually also aware of the availability and the generosity of public transfers in the receiving country. Of these transfers, old-age pension transfers are the largest. But for migrants, who tend to be young, the issue of pension benefit levels is usually too remote to factor into their migration decisions. Thus, migrants are more likely to think about access to short-term income from unemployment or social assistance schemes than about income in retirement. However, when income allocation over the life course is considered, old-age pensions are quite significant.

\footnotetext{
${ }^{1}$ For more on the demographic dividend, see Góra (2013).
} 
Under most legal frameworks, benefits from voluntary additional pension schemes are transferable across borders. In most cases, however, the benefits from such additional schemes are small compared to the benefits from basic schemes, which are usually harmonised ex-post according to either binational or multinational agreements. This ex-post harmonisation does not reduce the ex-ante uncertainty that matters for migration decisions.

Our aim is to analyse migration decisions made in a hypothetical institutional environment that undergoes (also hypothetical) changes. The hypothetical cases are based on assumptions that reflect the general pension landscape, and the dominant forecasts of how this landscape will change in the pension literature.

We focus on permanent migrants who (if they move) plan to work legally and retire in the destination country. Temporary or return migrants, as well as migrants who engage in unregistered work, are thus beyond the scope of our paper. For temporary migrants who work legally, bilateral agreements or the harmonisation of European pension entitlements matter more than the pension system in the destination country. Migrants who work temporarily in the shadow economy only benefit from the difference in the available wages between their home country and their destination country.

Our main hypothesis is that a decision to migrate that does not take into consideration pension entitlements might not be optimal from the point of view of individual discounted lifetime incomes. The other side of that hypothesis is that awareness of lifetime income sensitivity to migration decisions may change actual migration patterns. Our assumption is that people are increasingly aware of the need for pension reforms that will lead to reductions in the generosity of pension benefits.

Large migration flows could change the sustainability of pension systems in both sending and receiving countries. We do not analyse that effect, since it can hardly be perceived ex-ante when migration decisions are taken. Moreover, flows of permanent labour migrants between countries will not significantly influence the probability of a pension system reform, as they are too small to have a lasting impact on the demographic structure of the population (see Bijak et al., 2013). We therefore analyse the impact of expectations regarding pension system reforms on migration, but not the impact of migration flows on pension systems.

\section{PENSION DRIVERS BEHIND MIGRATION DECISIONS}

In most countries, pension reforms are being discussed or have already been implemented. Thus, public awareness of the inevitability of diminishing pension generosity has grown. In light of these reforms, people expect to retire later, to have smaller benefits in the future, or to need more supplementary savings for their old age. However, all of the existing empirical analyses on this topic have focused on expectations or observed changes in the behaviour of people already living in a country that has introduced pension reforms; see: Okumura and Usui 
(2014) for Japan, Boeri and Brugiavini (2008) for Italy, or Dominitz and Manski (2006) for the United States. To our knowledge, our paper is the first attempt to include pension wealth and pension expectations in the analysis of migration.

Given this context, the following question arises: Will international migration lead to better, similar, or worse pension prospects for individuals? For instance, migration from a country where levels of pension generosity are decreasing quickly or steeply to a country where the reform process is occurring more gradually may lead to an increase in the lifetime income of an individual (assuming his/her wages remain the same), and vice versa. Thus, the pace and the extent of pension reforms in both countries will affect the outcome of migration, defined as the discounted lifetime income after migration. However, such theoretical and practical considerations may not enter into the individual's decision about whether to migrate.

Ambiguous expectations related to pension reforms cannot be analysed on the basis of data. In the second half of the $20^{\text {st }}$ century - again, thanks to the demographic dividend - pension systems were very stable and predictable public institutions, and thus became a "natural" element of the institutional structure of European countries. The availability and generosity of other benefits may have fluctuated, but pensions were never threatened. In order to protect migrants, countries concluded bilateral or multilateral agreements on procedures for the establishment, the payment, and the financing of pension benefits for people who had worked in more than one country. ${ }^{2}$ Because they felt protected by these agreements, most people did not take into account how their decision to migrate would affect their pension benefits. However, these social security and pension institutions are no longer stable. Moreover, the agreements to protect migrants are retroactive. This means they are activated ex-post, after a person finishes working career. When these institutions were stable, this system was sufficient.

Today, however, these existing regulations seem insufficient. This is the subject of not only professional but also of public debates. The media are full of messages stressing pension system problems. So potential migrants are probably increasingly aware of the need for pension reforms and other measures aimed at reducing expenditures in response to changing demographic structures. Thus, potential migrants are increasingly seeking ex-ante information on the coming changes. If individuals are unable to get such information, they may reconsider their migration plans because of risk aversion. Moreover, countries may apply (openly or surreptitiously) policies or regulations that are less beneficial for immigrants than for locals. For example, a country's pension system may provide more generous benefits to workers who contributed to the social security insurance for longer periods of time. Even if such policies have not yet been implemented, potential migrants may be worried about future pension system changes.

\footnotetext{
${ }^{2}$ Harmonisation of social security systems in the EU is an example.
} 
There are two broad strands of migration literature. The first strand focuses on macroeconomic theoretical models and empirical approaches, while the second focuses on the microeconomic analysis of migration decisions. Pension systems are not analysed separately as a factor that influences migration flows, as they are usually included in the destination country welfare system. At the macro level, researchers have analysed the fiscal effects or the net effects (the net present value of taxes and contributions paid by the migrant minus the welfare benefits received by migrant households). Over the last decade, the fiscal impact of immigration has become an increasingly important topic in policy debates (OECD, 2013). Recent examples of research on this issue include a study by Chojnicki and Ragot (2016) that focused on the impact of migration policy on the tax burden associated with the ageing population in France, and a study by Kaczmarczyk (2015) that described the effects of Ukrainian migration on Poland.

Microeconomic analyses have attempted to identify the drivers of the decision to migrate. Whether an individual decides to migrate depends on a number of factors. Starting in the 1960s, the theoretical literature focused on the theory of human capital investment. Most of this literature explained movements based on Hicks' (1932) idea that the main cause of migration is the difference between the wage levels in the home country and in a destination country. The upfront costs of migration were considered an investment that should be followed by a payoff in the future; i.e., higher wages. If wages measure returns to individual human capital, migration increases these returns (Borjas 1987; 1999). In the last decades of the $20^{\text {th }}$ century, researchers suggested that differences in welfare state arrangements across countries may also influence the decision about where to migrate. These studies investigated whether migrants (or asylum seekers) move to countries with more generous welfare systems, and if they do, what type of migrant they are. They found that migration decisions are mainly influenced by the availability of short-term unemployment and family benefits (see Borjas, 1999; McKinnish, 2007; De Giorgi and Pellizzari, 2009; Kurekova, 2013; Josifidis et al., 2014). Some researchers, such as Razin and Wahba (2015), suggested that social security benefits could be more important to lower educated migrants, as they provide insurance against higher labour market risk. Generally, the welfare magnet hypothesis in the migration literature argues that the generosity of welfare systems may influence both the quantity and the skill composition of migration flows (Borjas, 1999; Razin and Wahba, 2015). However, in these studies, welfare systems were analysed as a whole, and pension systems were not treated separately. ${ }^{3}$

There is no existing literature on the role of pension system benefits in the decision to migrate, even though decisions about when and where to migrate influence not only a worker's wages, but also his/her income after retirement. The debate on social security in times of demographic change made has led many developed

\footnotetext{
${ }^{3}$ One of the reasons could be the small size of the retired migrant population in the most popular immigration countries. The migrants who arrived in Western Europe in the 1960s and the 1970s are approaching retirement age or are recently retired.
} 
countries to reform their pension systems (see, e.g., OECD, 2015). Some countries have introduced reforms that are more "actuarially fair", with a stronger link between pension benefits and individual contributions. In other countries, there is a broad spectrum of redistribution approaches, in which, for example, the replacement rates depend not only on individual contributions, but on other factors as well. An important aim of every pension system is to ensure its fiscal sustainability while providing adequate retirement income to protect older people against poverty.

In many countries, the reform process is ongoing, and insured individuals can be entitled to different pension benefit levels depending on their tenure and the time at which they entered the system. Reforms may affect the relationship between lifetime pension benefits and lifetime contributions (see, e.g., Fredriksen and Stølen (2017) for Norway), or they may change the relative pension wealth available to different generations (Miles and Iben, 2000).

Our model contributes to the existing knowledge on microeconomic determinants of migration. We do not differentiate between highly skilled and low skilled migrants, and instead focus on all legal permanent labour migrants. We assume that refugees have other reasons for migrating, and that temporary migrants do not think about the pension benefits in a receiving country.

\section{THEORETICAL MODEL}

We attempt to extend the model as presented in Burda (1995). The basis for his approach was the assumption that observed migration is sluggish due to uncertainty about the future development of wage differences between the home and the destination country, or about labour market conditions in general. Burda modelled procrastination using the value of the option to wait for information.

In Burda's basic model, a person can migrate in the first period, or postpone the decision until the next period. The migration costs are fixed and irreversible. As the benefits of migration are uncertain, waiting can allow for new information to become available. For the simple two-period analysis, an individual migrates in the first period when:

$$
-F+W_{1}+\left(\frac{p^{G} W_{2}^{G}+p^{B} W_{2}^{B}}{1+r}\right)>\frac{\left(W_{2}^{G}-F\right) p^{G}}{1+r}
$$

where:

$F$ - the upfront migration costs;

$r$ - the discount rate between periods 1 and 2;

$W_{1}$ - the difference in income in period 1 between the home country and the destination country - for simplicity, measured as the difference in wages;

$W_{2}^{G}$ - the difference in wages in period 2 in a "good" scenario (favourable for migrants);

$W_{2}^{B}$ - the difference in wages in period 2 in a "bad" scenario (unfavourable for migrants); 
$p^{G}$ - the probability of the good scenario;

$p^{B}$ - the probability of the bad scenario;

and $p^{G}+p^{B}=1$.

In the opposite situation; i.e., when

$$
-F+w_{1}+\left(\frac{p^{G} W_{2}^{G}+p^{B} W_{2}^{B}}{1+r}\right)<\frac{\left(W_{2}^{G}-F\right) p^{G}}{1+r}
$$

a person should postpone the decision about whether to migrate to period 2 .

The left-hand side of the inequalities above is $\mathrm{NPV}_{1}$ - the net present value of expected income flows when migration takes place in period 1; and the right-hand side is $\mathrm{NPV}_{2}$ - the net present value of the expected income flows when migration takes place in period 2 .

Burda (2005: 8) defined the function $V^{W}$ that could be called the option value of waiting. It is defined as "the excess of the value of the waiting strategy over the classical expected net present discounted value when migration is undertaken immediately". Generally, migration occurs when this value equals zero; when it is larger than zero, the optimal strategy is to wait and decide whether to migrate in period 2.

$$
V^{W}\left(w_{1}\right) \equiv \frac{F\left(r+p^{B}\right)}{1+r}-w_{1}-\frac{p^{B} W_{2}^{B}}{1+r}>0
$$

The value of this migration option decreases in the current wage gap and in the bad scenario wage gap in the second period, and increases in the fixed migration costs and the probability of the bad scenario. It is independent of the wage difference in the good scenario. The discount rate has an ambiguous effect on $V^{W}$. The option value increases in $r$ when $\left(1-p^{B}\right) F>-p^{B} W_{2}^{B}$ and decreases in $r$ when $\left(1-p^{B}\right) F<-p^{B} W_{2}^{B}$.

In our model, the gain or the loss from the decision to migrate stems not only from the wage differential, but also from the old-age benefit differential. Instead of two periods, we have three periods. The second and third periods correspond to the first and second periods of the models in Burda (1995), respectively. If the decision to migrate is postponed to the second period, then in the initial period, the person is working and accumulating pension rights in a sending country. Thus, a decision to migrate can be taken at the beginning of the first or of the second period. In our model, the risk is associated not only with wage dynamics, but also with the pace of pension reforms in both countries. In the last period, a migrant's pension benefit entitlement depends on the pension rights accrued in both the sending and the receiving country. 


\subsection{MIGRATION WITH NO UNCERTAINTY ABOUT FUTURE PENSION SYSTEM RULES}

First, let us consider the situation in which the rules of the pension system in the sending and receiving countries are known and constant. In this case, pension wealth depends on the linkage between wage levels, contributions paid, and pension benefits. Table 1 shows how pension entitlements should be incorporated into migration decisions.

\section{TABLE 1}

Returns to migration including pension entitlements without pension system reform

\begin{tabular}{|c|c|c|c|}
\hline & Period 1 & Period 2 & Period 3 \\
\hline $\begin{array}{l}\text { Migrate in } \\
\text { p.1 }\end{array}$ & $\begin{array}{l}\text { Work abroad } \\
-F+W_{1}\end{array}$ & $\begin{array}{c}\text { Work abroad } \\
p^{G} W_{2}^{G}+p^{B} W_{2}^{B}\end{array}$ & $\begin{array}{c}\text { Retirement } \\
B_{3}\left(W_{1}, p^{G} W_{2}^{G}+p^{B} W_{2}^{B}\right)\end{array}$ \\
\hline $\begin{array}{l}\text { Wait until } \\
\text { p.2 }\end{array}$ & Home country work & $\begin{array}{l}\text { Work abroad } \\
p^{G}\left(-F+W_{2}^{G}\right)\end{array}$ & $\begin{array}{c}\text { Retirement } \\
p^{G} B_{3}\left(W_{2}^{G}\right)+B_{H}\end{array}$ \\
\hline Stay & Home country work & Home country work & Home country retirement \\
\hline
\end{tabular}

We introduced $B_{3}($.$) - the difference in pension benefits depending on the wage$ levels and the pension system rules in the destination country and in the home country. Here, we should account for $B_{H}$; i.e., the pension rights an individual accrued in his/her home country before migration if he/she worked there in period 1. The other variables are the same as in the Burda approach.

When a person migrates in the first period, NPV equals:

$$
N P V_{1}=-F+W_{1}+\frac{p^{G} W_{2}^{G}+p^{B} W_{2}^{B}}{1+r}+\frac{B_{3}\left(W_{1}, p^{G} W_{2}^{G}+p^{B} W_{2}^{B}\right)}{(1+r)^{2}}
$$

When migration occurs in the second period, NPV equals:

$$
N P V_{2}=\frac{p^{G}\left(-F+W_{2}^{G}\right)}{1+r}+\frac{p^{G} B_{3}\left(W_{2}^{G}\right)+B_{H}}{(1+r)^{2}}
$$

As in the case without pension benefits, an individual should migrate in the first period when $N P V_{1}>N P V_{2}$, and should wait until the second period when $N P V_{1}<N P V_{2}$.

The option value of waiting $V^{W, B}$ should now be $V^{W}\left(w_{1}\right)$ (formula (3)) increased by a change in the discounted pension wealth when a person migrates in the second period rather than in the first period; i.e.:

$$
\frac{p^{G} B_{3}\left(W_{2}^{G}\right)+B_{H}}{(1+r)^{2}}-\frac{B_{3}\left(W_{1}, p^{G} W_{2}^{G}+p^{B} W_{2}^{B}\right)}{(1+r)^{2}}
$$


It is the value of waiting for information on both wage development and the implemented pension system reforms. If the pension strongly depends on individual wages, waiting until the second period allows the migrant to gain more knowledge about lifetime income (including old-age pension benefits).

Migrants can return to their home country before retirement. If they retire according to the regulations of their home country their pension rights have local and foreign components. We do not cover return migrants in our model, as we assume that the additional risk stemming from the two factors is much smaller for temporary migrants than it is for permanent migrants. We also do not cover migrants who return to their home country after retiring in their receiving country, since as retirees from a foreign system, they remain subject to the regulations of that system even if they are living abroad. Pension reforms and their unknown scope and time dynamics do not directly affect decisions to return to the home country after retirement. As there is no pension system reform-dependent risk it is beyond the scope of our paper.

A person who migrates in the first period is treated as a local, while a person who migrates later has the status of a migrant. These two types of migrants may be affected differently by a reduction in future old-age benefits. This differentiation extends the model. Waiting has an additional value. Beyond including the conventional risk of waiting, we include the risk that the replacement rate reduction in the destination country will be larger than it is in the source country (or vice versa). The second risk is the possibility that migrants will be penalised vis-à-vis locals. In the source country, the individual who migrated is by definition a local; while in the destination country, he is considered a local if he migrated early, and he is considered a migrant if he migrated late.

This expression should be negative in countries where individuals who contribute for a shorter period of time but with higher wages just before retirement could expect a higher ratio of lifetime pension benefits to lifetime contributions. That is the case in some older types of public defined-benefit pension systems in developed countries.

To sum up, this simple example shows that expected pension wealth can have an impact on the optimal timing of retirement.

\subsection{MIGRATION WITH UNCERTAIN PENSION REFORM}

As we discussed above, many countries are considering or introducing changes to pension systems. As it is usually difficult to reach a broad consensus on the details of pension reforms (Holzmann, Orenstein and Rutkowski, 2003; Góra 2013), we assumed that there is some degree of uncertainty about future levels of pension wealth and the timing of the implementation of reforms. We assume that if reforms in one or both countries are implemented in period 2, they will influence the expected pension wealth of a migrant; but that if reforms are implemented in period 3 or later, only subsequent generations will be affected. 
Waiting until the second period to decide whether to migrate can allow the individual obtain more information not only about wage differentials, but also about the potential impact of pension system reforms.

Table 2 shows returns to migration when the direction or scope of the pension reform is uncertain.

TABle 2

Returns to migration including pension entitlements with the pension system reform

\begin{tabular}{|c|c|c|c|}
\hline & Period 1 & Period 2 & Period 3 \\
\hline $\begin{array}{l}\text { Migrate in } \\
\text { p.1 }\end{array}$ & $\begin{array}{l}\text { Work abroad } \\
-F+W_{1}\end{array}$ & $\begin{array}{c}\text { Work abroad } \\
p^{G} W_{2}^{G}+p^{B} W_{2}^{B}\end{array}$ & $\begin{array}{c}\text { Retirement } \\
q^{G} B_{3}^{G}\left(W_{1}, p^{G} W_{2}^{G}+p^{B} W_{2}^{B}\right) \\
+q^{B} B_{3}^{B}\left(W_{1}, p^{G} W_{2}^{G}+p^{B} W_{2}^{B}\right)\end{array}$ \\
\hline $\begin{array}{l}\text { Wait until } \\
\text { p.2 }\end{array}$ & $\begin{array}{l}\text { Home country } \\
\text { work }\end{array}$ & $\begin{array}{l}\text { Work abroad } \\
p^{G}\left(-F+W_{2}^{G}\right)\end{array}$ & $\begin{array}{c}\text { Retirement } \\
q^{G} p^{G} B_{3}{ }^{G}\left(W_{2}^{G}\right)+B_{H}\end{array}$ \\
\hline Stay & $\begin{array}{l}\text { Home country } \\
\text { work }\end{array}$ & $\begin{array}{l}\text { Home country } \\
\text { work }\end{array}$ & Home country retirement \\
\hline
\end{tabular}

Here, $B_{3}{ }^{G}($.) denotes the pension benefit depending on the wages and the pension system rules if the reform is favourable for future employees (a higher ratio of lifetime pensions to lifetime contributions),

$B_{3}{ }^{B}($.$) - the pension benefit if the pension reforms in the destination country are$ less favourable for future employees than in the home country (a lower ratio of lifetime pensions to lifetime contributions),

and $B_{3}{ }^{G}()>.B_{3}{ }^{B}($.$) .$

$q^{G}$ - the probability of the favourable pension reform scenario in the destination country,

$q^{B}$ - the probability of the unfavourable pension reform scenario in the destination country, and $q^{G}+q^{B}=1.4$

Reforms in the home country and in the foreign country are implemented in period 2. Thus, in period 1, a potential migrant knows (or expects) changes with a certain probability; and in period 3, the pension rules for period 3 are known. Now, NPV when a person migrates in the first period equals:

$$
\begin{aligned}
& N P V_{1}=-F+W_{1}+\frac{p^{G} W_{2}^{G}+p^{B} W_{2}^{B}}{1+r}+ \\
& +\frac{q^{G} B_{3}^{G}\left(W_{1}, p^{G} W_{2}^{G}+p^{B} W_{2}^{B}\right)+q^{B} B_{3}^{B}\left(W_{1}, p^{G} W_{2}^{G}+p^{B} W_{2}^{B}\right)}{(1+r)^{2}}
\end{aligned}
$$

${ }^{4}$ That further simplifies the calculations. The situation without uncertain pension reforms is described in section 3.1 . 
NPV when the migration occurs in the second period after favourable outcomes in both the wage (labour market) and the pension system situations equals:

$$
N P V_{2}=\frac{p^{G}\left(-F+W_{2}^{G}\right)}{1+r}+\frac{q^{G} p^{G} B_{3}^{G}\left(W_{2}^{G}\right)+B_{H}}{(1+r)^{2}}
$$

When $N P V_{1}<N P V_{2}$ (the option value of waiting is positive), it is better to postpone migration.

When we set $W_{2}^{e}=p^{G} W_{2}^{G}+p^{B} W_{2}^{B}$, then the option value of waiting for additional information available in period 2 is:

$$
\begin{aligned}
& V^{W, B}=N P V_{2}-N P V_{1} \\
& =V^{W}\left(w_{1}\right)+\frac{q^{G} p^{G} B_{3}^{G}\left(W_{2}^{G}\right)}{(1+r)^{2}}+\frac{B_{H}}{(1+r)^{2}}-\frac{q^{G} B_{3}{ }^{G}\left(W_{1}, W_{2}^{e}\right)}{(1+r)^{2}}-\frac{q^{B} B_{3}{ }^{B}\left(W_{1}, W_{2}^{e}\right)}{(1+r)^{2}}= \\
& =V^{W}\left(w_{1}\right)+\frac{q^{G} p^{G} B_{3}^{G}\left(W_{2}^{G}\right)}{(1+r)^{2}}+\frac{B_{H}}{(1+r)^{2}}-\frac{\left(1-q^{B}\right) B_{3}{ }^{G}\left(W_{1}, W_{2}^{e}\right)}{(1+r)^{2}}-\frac{q^{B} B_{3}{ }^{B}\left(W_{1}, W_{2}^{e}\right)}{(1+r)^{2}}= \\
& =V^{W}\left(w_{1}\right)+\frac{q^{G} p^{G} B_{3}^{G}\left(W_{2}^{G}\right)}{(1+r)^{2}}+\frac{q^{B}\left[\left(B_{3}{ }^{G}\left(W_{1}, W_{2}^{e}\right)-B_{3}{ }^{B}\left(W_{1}, W_{2}^{e}\right)\right]\right.}{(1+r)^{2}}+ \\
& +\frac{B_{H}}{(1+r)^{2}}-\frac{B_{3}{ }^{G}\left(W_{1}, W_{2}^{e}\right)}{(1+r)^{2}}
\end{aligned}
$$

The important parts of our model are the probabilities of wage developments in the labour markets of both the sending country and the receiving country, and the probabilities of favourable and unfavourable reforms in both countries. Waiting until the second period decreases the risk of exposure to low wage differentials and unfavourable pension reforms (from an individual point of view), but increases the risk of exposure to a penalty for migrants $v i s$-à-vis locals, whereby workers with shorter tenures in the destination country pension system are disadvantaged relative to workers with longer tenures.

The greater the difference $B_{3}{ }^{G}\left(W_{1}, W_{2}{ }^{e}\right)-B_{3}{ }^{B}\left(W_{1}, W_{2}{ }^{e}\right)$ is between "favourable" and "unfavourable" pension reform outcomes, the higher the option value of waiting. Larger pension entitlements for even short contributory periods in the home country also increase the value of waiting. Relatively high $B_{3}{ }^{G}$ decreases the value of waiting, but it also depends on the probability of "bad" or "good" wage development.

In period 2, the person will decide to migrate if the situation is "good-good", but may be uncertain about the optimal decision if the situation is mixed ("bad wagegood pension" or "good wage-bad pension"). In both cases, $N P V_{2}$ is lower than in the "good-good" case and is equal to: 


$$
N P V_{2}=\frac{p^{B}\left(-F+W_{2}^{B}\right)}{1+r}+\frac{q^{G} p^{B} B_{3}^{G}\left(W_{2}^{B}\right)+B_{H}}{(1+r)^{2}}
$$

in the "bad-good" case, or

$$
N P V_{2}=\frac{p^{G}\left(-F+W_{2}^{G}\right)}{1+r}+\frac{q^{B} p^{G} B_{3}^{B}\left(W_{2}^{G}\right)+B_{H}}{(1+r)^{2}}
$$

in the "good-bad" case.

Contrary to the basic Burda model, a person may migrate in the second period even if the wage development scenario is unfavourable if the pension system changes provide for higher expected benefit levels at retirement in the destination country, thereby offsetting the lower wages.

\section{GOING BEYOND THE BASIC MODEL}

To the best of our knowledge, there are no data on the pension reform expectations of potential migrants over a horizon of decades. As it is impossible to test the model on real data, we have generated and discussed a number of hypothetical situations. Even if these expectations have little or no effect on current migration decisions, this may change as the pressure on pension systems becomes more acute. Our model is an attempt to create a conceptual framework for thinking about developments that will likely intensify as awareness grows of the impact of inevitable pension reforms on the generosity of retirement benefits. Thus, workers may be expected to become increasingly aware of how pension system changes will affect their lifelong wealth.

\subsection{RELATIVE LEVEL OF WAGES}

In line with Burda, our model starts with the standard assumption that migration only occurs when the expected wages in the destination country are higher than the wages in the home country. Thus, when the wages are the same or higher in the country of origin, people will decide not to migrate. The decision to stay is even more likely if people take migration costs into account.

Including pension benefits can change the optimal decision when the current or the expected pension formula gives more generous pension benefits for the same contributions.

\subsection{RELATIVE LEVEL OF PENSION BENEFITS}

Two cases are possible: a person is considering migrating from the country with a less generous pension system to the country with a more generous system, or vice versa. When the generosity of the pension system is the same in both countries, our model reduces to Burda (1995). Old-age pensions are neutral for migration decisions. 
In the more interesting case, the generosity of the pension system does not increase linearly with the contributory period, but individuals with a short working career in the destination country receive less than those who decided to migrate in the first period. Such a situation increases $N P V_{1}$ ceteris paribus.

\subsection{VESTING PERIOD}

Whether migrants receive pension benefits after a short vesting period in the sending country also matters. A positive change in pension wealth is more probable if a long minimum contributory period is a prerequisite for receiving pension benefits from the home country. In such a case, migrating in the first period becomes more attractive. A similar situation occurs if the receiving country's pension system rewards long contributory periods. There are three possible cases: no vesting period in the destination country, a short vesting period in the destination country (a migrant is entitled to full pension benefits after working for just one period in the new country), a long vesting period (a migrant is entitled to full pension benefits only after working for two periods in the new country).

The no vesting period case concerns countries that offer a basic, usually a flat-rate pension benefit to every person at retirement age. Such a case simplifies the initial analysis of a payoff from migration. In our notation, a change in the discounted pension wealth when a person migrates in the second period relative to when a person migrates in the first period - equation (6) - equals zero.

The second case, with the short vesting period, is the one presented in the models above.

The last case means that equation (8) reduces to:

$$
N P V_{2}=\frac{p^{G}\left(-F+W_{2}^{G}\right)}{1+r}+\frac{B_{H}}{(1+r)^{2}}
$$

... decreasing the option value of waiting until period 2.

A long vesting period can be a way to treat natives and migrants differently in the pension system, just as regulations that have been discussed or adopted in existing welfare schemes aim to limit access to short-term social benefits, and especially social assistance (see, e.g., Fernandes 2016).

\subsection{RISK OF A PENSION SYSTEM REFORM}

In our model, the implementation of pension reforms in the sending country as well as in the destination country will happen in the second period. The reforms will not be coordinated, so they will generate different outcomes for workers. The reforms will inevitably lead to a reduction in the generosity of the systems. With probability $q^{G}$, the changes will be favourable for the migrant, and with probability $q^{B}$, the changes will be unfavourable for the migrant. Favourable changes mean 
that for the same value of contributions paid, a person receives higher pension benefits in period 3 than he/she would if he/she had not migrated..$^{5}$ In our model, we can analyse two types of problems, namely: (1) how pension reforms will affect workers' lifetime income assuming they actually migrate; and (2) how pension reform expectations affect migration decisions. Let us first assume that the workers in question know the values of those probabilities. In this case, higher $q^{G}$ influences discounted pension wealth in an ambiguous way - i.e., depending on whether pensions are closely linked to wages.

$\frac{q^{G} p^{G} B_{3}{ }^{G}\left(W_{2}^{G}\right)+B_{H}}{(1+r)^{2}}-$

$\frac{q^{G} B_{3}{ }^{G}\left(W_{1}, p^{G} W_{2}^{G}+p^{B} W_{2}^{B}\right)+q^{B} B_{3}{ }^{B}\left(W_{1}, p^{G} W_{2}^{G}+p^{B} W_{2}^{B}\right)}{(1+r)^{2}}$

Pension reforms may positively or negatively affect a migrant's lifetime income depending on the timing and the scale of the reforms in the sending country and in the destination country. The actual outcome will depend on the comparison of pension reform developments. Ex-ante, workers can only approximate the probabilities of elements of such developments, as these are subjective probabilities based on their expectations.

\subsection{PERCEIVED RISK OF A PENSION SYSTEM REFORM}

Workers are generally not aware of the possible positive or negative pension outcomes of their potential migration; or if they take such outcomes into account, future pension income is likely only one of a range of factors they are considering. We assume that this awareness will increase, and could start to affect migration decisions. Whether pension benefit levels represent a stronger or a weaker motivation to migrate will depend on subjective perceptions of pension reform risk. However, the growing awareness of the possible impact of pension reforms may also weaken the motivation to migrate, because of human risk aversion. Unpredictable old-age pension system reforms will frighten workers, who will prefer to stay rather than to migrate.

\section{CONCLUDING REMARKS}

In this paper, we pointed out that uncertainty about the future outcomes of participation in basic/public pension systems will increasingly affect migration decisions. While people are becoming more aware of the inevitability of pension reforms, the exact timing and the scale of future pension reforms are uncertain. Pension benefits should be taken into account in addition to other migration drivers when analysing changes in returns to human capital after migration. This analysis expands the literature on how welfare systems affect mobility patterns, which has up to now focused mainly on short-term welfare benefits.

\footnotetext{
${ }^{5}$ We analyse the pension reforms in the destination country, but the results for the unfavourable reform or the favourable reform will be the same in the sending country.
} 
According to microeconomic analyses of individual decisions about whether and where to migrate, the key driver of migration is the difference in wages. The literature has also suggested that the availability of generous short-term social benefits could motivate migration decisions. In this paper, we have attempted to extend the list of factors that could influence migration decisions by adding expected differences in the generosity of old-age pension benefits, and by showing that ongoing pension reforms introduce uncertainty about the level of pension benefits that will be available to workers after migration. Smaller or larger pension reforms will probably moderate rather than encourage migration.

Our main conclusions are:

- Today, when most countries have completed or are in the last stage of the demographic transition, people may make sub-optimal migration decisions if they do not take into consideration future wealth from pension benefits.

- Even if potential migrants know the current rules of the pension systems in both the sending and the receiving countries, they face uncertainty because of the risk of future pension system reforms. They may experience a reform-driven decrease in welfare stemming from the scope and the timing of the reforms in the receiving country vis-à-vis the scope and the timing of the reforms in the sending country.

- Including expected pension benefits in the analysis of migration drivers may change the optimal timing of migration.

- The more risk averse potential migrants are, the less motivated they will be to migrate when they are aware of the inevitability of pension reforms.

These are forward-looking conclusions based on a theoretical model that includes new factors reflecting developments that have just started to affect migration decisions.

Based on our findings we also see several areas of possible future research expanding our approach. First, the discount factor can change in time. Here e.g. the assumption about the hyperbolic discounting by individuals (see Frederick, Loewenstein and O'Donoghue, 2002) can to some extent explain why people do not take benefits from the pension system into consideration in their migration decisions. Second, in future, when data on migration and retirement behaviour in the reformed pension systems are available, it would be worth adding empirical analysis to the theoretical model.

\section{Disclosure statement}

No potential conflict of interest was reported by the authors. 
1. Bijak, J. [et al.], Population Ageing, Population Decline and Replacement Migration in Europe. In: M. Kupiszewski, ed. International Migration and the Future of Populations and Labour in Europe. The Springer Series on Demographic Methods and Population Analysis, vol 32, pp. 245-263. https://doi. org/10.1007/978-90-481-8948-9_14

2. Boeri, T. and Brugiavini, A., 2008. Reforms and Women Retirement Plans. IZA Discussion Paper, No. 3821. http://dx.doi.org/10.1111/j.0042-7092.2007. 00700.x

3. Borjas, G., 1987. Self-selection and the earnings of immigrants. American Economic Review, 77, pp. 531-553.

4. Borjas, G., 1999. Immigration and Welfare Magnets. Journal of Labor Economics, 17(4), pp. 607-637. https://doi.org/10.1086/209933

5. Burda, M., 1995. Migration and the option value of waiting. The Economic and Social Review, 27(1), pp. 1-19.

6. Chojnicki, X., and Ragot, L., 2016. Impacts of Immigration on an Ageing Welfare State: An Applied General Equilibrium Model for France. Fiscal Studies, 37, pp. 258-284. https://doi.org/10.1111/j.1475-5890.2015.12059

7. De Giorgi, G. and Pellizzari, M., 2009. Welfare migration in Europe. Labour Economics, 16(4), pp. 353-363. https://doi.org/10.1016/j.labeco.2009.01.005

8. Dominitz, J. and Manski, C. F., 2006. Measuring pension-benefit expectations probabilistically. Labour, 20, pp. 201-36. https://doi.org/10.1111/j.1467-9914. 2006.00343.x

9. Fernandes, S., 2016. Access to Social Benefits for EU Mobile Citizens: “Tourism" or Myth? Policy Paper, No 168.

10. Frederick, S., Loewenstein F. and O'Donoghue T., 2002. Time discounting and time preference: a critical review. Journal of Economic Literature, 40, pp. 351-401. https://doi.org/10.1257/jel.40.2.351

11. Fredriksen, D. and Stølen, N. M., 2017. Life time pension benefits relative to life time contributions. International Journal of Microsimulation. 10(2), pp. 177-207.

12. Góra, M., 2013. Political economy of pension reforms: selected general issues and the Polish pension reform case. IZA Journal of Labor \& Development, 2: p. 2. https://doi.org/10.1186/2193-9020-2-2

13. Holzmann, R., Orenstein, M. A. and Rutkowski, M., 2003. Pension Reform in Europe: Process and Progress. Washington: The World Bank. https://doi. org/10.1596/0-8213-5358-6

14. Josifidis, K., Pucar, E. and Srdic, S., 2014. Labour migration flows: EU8+2 vs EU-15. Journal of Business Economics and Management, 15, pp. 41-55. https://doi.org/10.3846/16111699.2013.841283

15. Kaczmarczyk, P., 2015. Burden or Relief? Fiscal Impacts of Recent Ukrainian Migration to Poland. IZA Discussion Paper, No. 8779. 
16. Kureková, L., 2013. Welfare Systems as Emigration Factor: Evidence from the New Accession States. Journal of Common Market Studies, 51(4), pp. 721-739.

17. McKinnish, T., 2007. Welfare-Induced Migration at State Borders: New Evidence from Micro-Data. Journal of Public Economics, 91, pp. 437-450. https://doi.org/10.1016/j.jpubeco.2006.09.002

18. Miles, D. and Iben, A., 2000. The Reform of Pension Systems: Winners and Losers Across Generations in the United Kingdom and Germany. Economica, 67, pp. 203-228. https://doi.org/10.1111/1468-0335.00204

19. OECD, 2013. International Migration Outlook 2013. Paris: OECD.

20. OECD, 2015. Recent pension reforms. In: Pensions at a Glance 2015: OECD and G20 indicators. Paris: OECD. https://doi.org/10.1787/pension_glance2015-4-en

21. Okumura, T. and Usui, E., 2014. The effect of pension reform on pensionbenefit expectations and savings decisions in Japan. Applied Economics, 46(14), pp. 1677-1691. https://doi.org/10.1080/00036846.2013.870654

22. Razin, A. and Wahba, J., 2015. Welfare Magnet Hypothesis, Fiscal Burden, and Immigration Skill Selectivity. Scandinavian Journal of Economics, (117), pp. 369-402. https://doi.org/10.1111/sjoe.12092 